\title{
EKSTENSIFIKASI AGRARIA SEKITAR HUTAN, DILEMA KEBUTUHAN LAHAN USAHATANI DAN TERPINGGIRNYA EKSISTENSI MASYARAKATNYA
}

\author{
Roosganda Elizabeth \\ BRIN/Pusat Sosial Ekonomi dan Kebijakan Pertanian \\ Email: roosimanru@yahoo.com \\ (Diterima 07-01-2022; Disetujui 27-01-2022)
}

\begin{abstract}
ABSTRAK
Semakin berkurangnya lahan pertanian menyebabkan kebijakan buka lahan baru usahatani di lahan marjinal dan lahan tidur kian mendesak, seiring meningkatnya pertambahan penduduk dan kebutuhan pangan. Bagi masyarakat sekitar hutan, dilakukannya ekstensifikasi lahan pertanian di sekitar hutan, ditenggarai mengganggu eksistensi budidaya di lahan sekitar kehidupan mereka sejak dulu. Dengan metode deskriptif kualitatif, tulisan ini bertujuan mengemukakan perspektif terjadinya dilema antara desakan kebutuhan lahan pertanian, terpinggirkannya eksistensi komunitas sekitar hutan, erosi dan pengrusakan hutan akibat intensifikasi pengelolaannya untuk lahan pertanian. Kekeliruan pengartian regulasi pemanfaatan lahan sekitar hutan dijadikan dasar legitimasi kekuasaan untuk kepentingan proyek pembangunan, walaupun hilangnya pemenuhan etika sebesar-besarnya kemakmuran rakyat sebagai resikonya. Dampak lainnya adalah terjadinya degradasi dan kerusakan hutan yang tidak saja karena pembukaan lahan baru, tetapi lebih diakibatkan penjarahan dan perambahan sebagai dampak kekeliruan pemahaman kebijakan pemerintah dalam pengelolaan lahan sekitar hutan. Teridentifikasi faktor-faktor yang menentukan keberhasilan atau kegagalan suatu kebijakan publik dalam program pembangunan dan pengelolaan sumberdaya hutan.
\end{abstract}

Kata kunci: intensifikasi, pengelolaan sumberdaya hutan, kearifan lokal, masyarakat sekitar hutan

\section{ABSTRACT}

Degradation and forest damage that happened effect and illegal logging, and governmental policy failure effect in forest resource management. The failure made legitimation power base by for the sake of development project, although the loss of biggest ethics as people prosperity accomplishment risk. This paper aim to propose factors determining failure or efficacy [of] a[n public policy in forest resource management and development program. Forest management by private sector and state (HPH) in Indonesia, at be situation that very concern, because break of the rules destroyed forest. Forest domination resource rights enforcing as mastered by state, making agraria forest function have dregs from its as requirement accomplishment local society live effort for traditional agriculture. Empowerment represent goals which will be reached, which can be existed with existence participate from community forest. Community forest participate very determine failure or efficacy of public program in development policy, and represent tool to reach enableness. The importance of people forest take care and remain order to own benefit looking into people forest by holistic in order to the development program target more conducive, usable so that as base to rebuild forestry world which have destroyed, and also maintain and and function continueing forever and ever

Keyword: intencification, forest resource management, local wisdom, community forestry

\section{PENDAHULUAN}

Kebutuhan lahan yang semakin

meningkat, tidak saja dari sisi nilai ekonominya, namun terutama dari fungsinya sebagai tempat usahatani, sumber matapencaharian mayoritas penduduk di 


\section{EKSTENSIFIKASI AGRARIA SEKITAR HUTAN, DILEMA KEBUTUHAN LAHAN USAHATANI \\ DAN TERPINGGIRNYA EKSISTENSI MASYARAKATNYA \\ Roosganda Elizabeth}

sekitarnya. Kondisi yang sedemikian rupa tersebut menyebabkan penduduk desa semakin terdesak ke daerah pinggiran di sekitar hutan. Areal hutan dan lahan sekitarnya menjadi komoditi utama bagi mereka. Pesatnya pertumbuhan penduduk, baik di daerah perkotaan maupun di pedesaan tentunya berdampak terhadap semakin terbatasnya lahan yang dapat diusahakan untuk usahatani memproduksi bahan pangan, aktivitas sosial dan ekonomi, dan pemukiman. Baik sebagai faktor produksi penghasil bahan pangan, tempat berlangsungnya berbagai kegiatan ekonomi, maupun yang dimanfaatkan sebagai pemukiman. Deforestasi dan degradasi hutan umumnya dipicu oleh tindakan egoistis dan kesewenangan suatu pihak yang hanya memikirkan keuntungan pribadi dan sesaat. Demikian halnya dengan penduduk asli di sekitar hutan. Mereka tentunya tetap saja membutuhkan lahan pertanian untuk diolah agar dapat menyediakan bahan-bahan pangan sehari-hari, dan tentunya dengan mengelola lahan areal hutan maupun sekitar hutan. Dengan metode deskriptif kualitatif, tulisan ini bertujuan mengemukakan perspektif terjadinya dilema antara desakan kebutuhan lahan pertanian, terpinggirkannya eksistensi komunitas sekitar hutan, erosi dan pengrusakan hutan akibat intensifikasi pengelolaannya untuk lahan pertanian. Pengelolaan yang arif, bijak dan sesuai dengan kondisi dan tekstur sumberdaya agraria hutan tentu sangat membutuhkan teknologi yang spesifik mengingat peran strategis hutan sebagai sumber serapan air dan udara suatu wilayah. Berkembang pesatnya pembukaan baru untuk mencukupi kebutuhan petani akan lahan pertanian sekitar hutan, pada akhirnya menimbulkan berbagai penyimpangan dan problema tersendiri terhadap kelestarian dan keberlanjutan hutan tersebut.

\section{Gambaran Umum Hutan Indonesia}

Di antara hasil pemantauan hutan Indonesia tahun 2020 menunjukkan bahwa luas lahan berhutan seluruh daratan Indonesia adalah 95,6 juta ha atau 50,9 dari total daratan, dimana 92,5 dari total luas berhutan atau 88,4 juta ha berada di dalam kawasan hutan, dan sesuai untuk usahatani, serta umumnya terletak di wilayah pedesaan baik yang berupa dataran yang relatif datar, maupun relatif berbukit. Hingga tahun 2019, luas lahan berhutan indonesia berkurang 1,6 juta ha sepanjang 2014-2019. Berdasarkan laporan Kementerian Lingkungan Hidup dan Kehutanan (KemenLHK) tahun 2020, daratan Indonesia terbagi atas lahan berhutan seluas 94,1 juta ha atau $50 \%$ dari luas total daratan dan lahan tidak berhutan dengan luas 93,6 juta ha pada 2019. Selama 2014 hingga 2019, luas lahan berhutan tanah air mengalami penurunan seluas 1,6 juta ha dari 95,7 ha pada 2014 menjadi 94,1 ha pada 2019. 
Tabel. Perkembangan Luas Lahan Berhutan di Indonesia (Juta Hektar) (2011-2019)

Tahun $2014 \quad 2015 \quad 2016 \quad 2017 \quad 2018 \quad 2019$

Luas

(juta

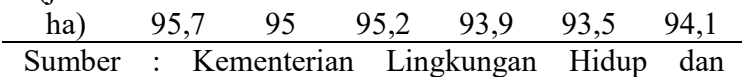

Kehutanan, 8/10/2021, 10.40 WIB

Kerusakan hutan akibat perubahan fungsi ataupun peruntukan hutan menjadi faktor utama penurunan luas lahan_berhutan. Pada 2019, penutupan lahan berhutan terluas terdapat di wilayah Papua, yakni 32,5 juta ha atau $34,5 \%$ dari total luas lahan berhutan nasional (94,1 juta ha). Diikuti oleh wilayah Kalimantan_seluas 24,7 juta ha atau 26,25\%. Wilayah Maluku, Sulawesi, dan Jawa memiliki lahan berhutan kurang dari 15\%. Sementara wilayah Bali dan Nusa Tenggara memiliki luas lahan berhutan yang terkecil yaitu 1,7 juta ha atau $1,81 \%$. Penutupan lahan berhutan dibedakan menjadi tiga kelompok berdasarkan fungsi, yaitu Hutan Produksi, Hutan Lindung, dan Hutan Konservasi. Masing-masing memiliki luas sebesar 68,8 juta ha, 29,7 juta ha, dan 21,9 juta ha pada 2019.

Perspektif terjadinya dilema antara kebutuhan lahan pertanian, erosi dan pengrusakan hutan dan peminggiran eksistensi komunitas sekitar hutan akibat intensifikasi pengelolaan sumberdaya agraria hutan dalam konteks mewujudkan solusi konflik pemanfaatan hutan yang lestari, berkesinambungan dan berkelanjutan. Akankah dicapai keberhasilan ataukah kegagalan sebagai dampak lanjutan suatu kebijakan publik dalam pengelolaan dan program pembangunan sumberdaya lahan hutan. Intensifikasi pengelolaan sumberdaya agraria hutan hendaknya merupakan reaktualisasi wawasan dan wacana policy maker untuk menyelenggarakan kebijakan yang berpihak pada sektor pertanian terkait upaya pemenuhan lahan usahatani sumber bahan pangan dan kehidupan komunitas sekitar hutan. Keberpihakan tersebut diharapkan dapat mengatasi konflik pemanfaatan hutan, bukannya meminggirkan kearifan lokal bahkan mengabaikan keberadaan komunitas sekitar hutan.

Hutan Indonesia merupakan sumber daya nasional penting yang harus memberikan manfaat sebesarbesarnya pada masyarakat, bukan hanya menguntungkan individu atau kelompok. Oleh karena itu, pemanfaatan sumber daya hutan hendaknya dilakukan melalui

keterlibatan dan memberdayakan seluruh unsur masyarakat serta mendorong mereka untuk menggunakan seluruh potensi yang dimiliki secara penuh. Pemerintah telah melaksanakan

program Perhutanan Sosial sebagai sebuah manifestasi komitmennya untuk memberdayakan masyarakat guna mengembangkan kapasitas mereka serta mendorong mereka berpartisipasi dalam pengelolaan hutan dengan cara yang adil dan ramah ingkungan, yang diharapkan dapat memfasilitasi pencapaian keamanan sosial dan ekonomi serta ketahanan terhadap ancaman eksternal. 


\section{EKSTENSIFIKASI AGRARIA SEKITAR HUTAN, DILEMA KEBUTUHAN LAHAN USAHATANI \\ DAN TERPINGGIRNYA EKSISTENSI MASYARAKATNYA \\ Roosganda Elizabeth}

Program prioritas nasional perhutanan sosial mencakup kegiatan pemberdayaan masyarakat, kewirausahaan masyarakat, pengembangan kelompok ekonomi dan mata rantai nilai, meningkatkan produktivitas, memberikan pengetahuan dan keterampilan kepada masyarakat, dan mencegah konflik terkait pengelolaan sumber daya alam. Sesuai dengan Rencana Pembangunan Jangka Menengah Nasional (RPJMN) 2015-2019, pemerintah telah mengalokasikan 12,7 juta hektar lahan hutan untuk dapat diakses oleh masyarakat melalui program Perhutanan Sosial, dengan menentukan lahan tersebut sebagai Hutan Kemasyarakatan (HKm), Hutan Desa (HD), Hutan Tanaman Rakyat (HTR), Hutan Adat, dan Kemitraan Kehutanan. Untuk mengembangkan program Perhutanan Sosial ini, masyarakat telah diberi dana dalam bentuk kredit bergulir untuk meningkatkan akses mereka terhadap modal dan pasar sebagai upaya untuk mencapai otonomi ekonomi (Kementerian KLHK. 2018).

\section{Terpinggirnya Kearifan Lokal dan Eksistensi Masyarakat Sekitar Hutan}

Terpinggirnya kearifan lokal dan eksistensi masyarakat sekitar hutan mencerminkan dan mengindikasikan potret kegagalan pengelolaan agraria hutan. Peran manusia di alam ini relatif kecil, dimana terdapat banyaknya perubahan-perubahan ekosistim adalah di luar keterlibatan manusia. Namun karena sikap/nilai antroposentris dan kontemposentris yang melekat dalam diri manusia sejak lahir, bisa menjadi sumber masalah. Nilai antroposentris adalah nilai dimana manusia menganggap dirinya sebagai mahluk yang paling sempurna, yang selalu menginginkan yang terbaik bagi dirinya sendiri. Nilai kontemposentris, dimana manusia yang lebih mementingkan keadaan masa kini saja (kontemporer) dibanding masa depan. Mahluk hidup (manusia) agar dapat bertahan hidup, berkembang biak, dan berkelanjutan harus mendukung dan melestarikan lingkungan hidup tersebut.

Fakta dan kondisi yang memprihatinkan tersebut membuktikan kebenaran tentang beragamnya bencana alam yang timbul akibat dari penebangan hutan membangkitkan semangat (arousal) untuk memcoba memperbaiki alam dan lingkungan hidup (LSM, Lembaga Green Ecology, Pemantau Korupsi Indonesia/ICW, dan sebagainya). Arousal tersebut diaktualisasi dengan mendesak pemerintah untuk tetap mengeluarkan undang-undang tentang pemberantasan praktik penebangan kayu secara liar (illegal logging), agar memperkuat koordinasi aparat penegak hukum membongkar dan menjerat secara hukum para sindikat mafia kayu dan jaringannya sampai tuntas. Kesemuanya ini mungkin dilakukan dengan dilatar belakangi environmental stress (dimana kedudukan lingkungan sebagai stressor) yang terjadi seperti makin rutin dan maraknya bencana alam, kacaunya musim dan iklim, temperatur udara yang tidak stabil, timbul dan meng- 
epideminya berbagai jenis penyakit dan lain sebagainya, yang dapat dianggap sebagai tanda-tanda (alarm reaction) yang dapat men-stress keadaan/kejadian selanjutnya.

Partisipasi masyarakat sekitar hutan turut menentukan berhasil tidaknya program pembangunan pertanian sekitar hutan, dan merupakan alat mencapai pemberdayaan. Pemberdayaan merupakan target yang dapat terwujud dengan partisipasi masyarakat sekitar hutan. Perlu penerapan peraturan (perundang-undangan) sebagai alat ancaman hukuman yang serius dan konsisten bukan hanya sebagai gertakan semata. Proses penyusunannya harus transparan dan partisipatif dengan berjalannya asas demokrasi serta melalui mekanisme yang bottom-up. Perlu memandang hutan rakyat secara holistik dan mempertimbangkan pengetahuan dan kearifan lokal, serta merestrukturisasi paradigma state-based forest management dengan paradigma community-based forest management, untuk mencapai pembangunan pertanian sekitar hutan yang berkualitas dan tetap memiliki keberlanjutan fungsi hutan serta manfaat selama-lamanya demi terwujudnya kesejahteraan masyarakat sekitar hutan. Paradigma lama yang bersifat state-based forest management (pengelolaan hutan yang berbasis Negara), berorientasikan produksi dan kekuasaan semata, ternyata sangat memarginalkan kepentingan masyarakat/ komunitas lokal sekitar hutan, dimana mereka berperan sebagai obyek, bukan sebagai pelaku utama (subyek) pembangunan. Pengelolaan hutan oleh negara dan swasta (HPH) di Indonesia, berada pada situasi yang sangat memprihatinkan, karena kebablasan dan kesewenangannya telah memporak porandakan hutan dan segala keberadaannya. Dari kekurang pahaman dalam mengartikan pasal 33, ayat (2) UUD 1945 tentang penguasaan dan pemanfaatan sebesarbesarnya oleh negara atas seluruh sumberdaya alam Indonesia merupakan awal kekeliruan kebijakan pemerintah dalam pengelolaan sumberdaya agraria hutan. Kekeliruan tersebut menyebabkan kerusakan hutan yang parah akibat penjarahan dan perambahan.

Pemaksaan hak penguasaan sumberdaya agraria hutan oleh negara, mengindikasikan tersingkirnya fungsi dan peluang pengusahaannya dalam memenuhi kebutuhan lahan sebagai faktor produksi pertanian masyarakat lokal tradisional. Kekeliruan tersebut diprediksi dijadikan juga dasar legitimasi kekuasaan untuk kepentingan proyek pembangunan, walaupun hilangnya pemenuhan etika sebesar-besarnya kemakmuran rakyat sebagai resikonya. Kesenjangan ini, menurut Dove (1992), menunjukkan kegagalan di pihak para pengambil kebijakan kehutanan (dan merupakan kegagalan program pembangunan kehutanan). Timbulnya partisipasi sangat ditentukan oleh manfaat sebagai insentif yang menarik minat petani untuk berperan. 


\section{EKSTENSIFIKASI AGRARIA SEKITAR HUTAN, DILEMA KEBUTUHAN LAHAN USAHATANI \\ DAN TERPINGGIRNYA EKSISTENSI MASYARAKATNYA \\ Roosganda Elizabeth}

Tanpa insentif manfaat tersebut, maka partisipasi akan berubah makna menjadi keterpaksaan dari sukarela (karena lahirnya harapan akan adanya perbaikan kehidupan). Untuk itu peran keterbukaan (transparansi) sangat dibutuhkan agar mengoptimalisasi pemberdayaan antusias masyarakat untuk turut berpartisipasi dalam suatu program kegiatan pembangunan karena sudah memperoleh pemahaman yang sama atas program tersebut. Pihak pengambil kebijakan di bidang kehutanan mengharapkan adanya partisipasi masyarakat dalam kegiatan pengelolaan lahan hutan dan sekitarnya untuk mencapai kelestarian dan fungsinya sebagai lahan pertanian. Akan tetapi, persepsi dan perilaku aparat pemerintah (pihak birokrat) seringkali tidak sesuai dengan harapan dan dibutuhkan masyarakat petani di sekitar hutan, tentang hutan dan fungsinya.

Kegagalan Pengelolaan Hutan: Erosi, Gundul, Degradasi Hutan, Deforestasi Parah

Dominasi dan penetrasi pemerintah terhadap hutan selama ini, dinilai kurang memperhatikan kelestarian lingkungan dan kesejahteraan komunitas sekitar hutan, yang secara sistematis akan menyebabkan degradasi dan deforestasi hutan yang parah. Degradasi hutan umumnya dipicu tindakan kesewenangan yang hanya memikirkan keuntungan pribadi oleh suatu pihak. Pembalakan hutan yang merajalela telah mengakibatkan terjadinya berbagai bencara alam, banjir, erosi, pendangkalan sungai, kekeringan yang parah, anomali iklim dan lonjakan suhu global karena hutan sebagai buffer alamiah telah gundul, dan berbagai bencana lainnya. Beberapa faktor penyebab kerusakan hutan misalnya: pembukaan hutan untuk perluasan pemukiman yang dilakukan dengan pembabatan pepohonan hutan secara sembarangan dan pembakaran dengan sengaja (slash and burn agriculture system), atau kebakaran hutan karena suhu yang terlalui tinggi, serta merajalelanya kuasa dan tindakan industri HPH.

Beberapa hal penting dalam memahami hutan rakyat yang dapat menyebabkan kegagalan dalam pengelolaannya, seperti: i) Secara ekologis, ekosistem hutan rakyat memiliki biodiversitas tinggi dibandingkan kawasan/areal budidaya lain, serta melahirkan sebuah sistem ketahanan pangan (food security); ii) Pengelolaan berdasarkan posisi geografisnya; iii) Kemampuan kelembagaan dan institusi lokal; iv) Dari segi ekonomi, terjadi pergeseran seiring beragamnya dinamika kehidupan petani hutan, juga dipengaruhi kondisi geografis, topografis, fungsinya sebagai paru-paru dunia, mampu memenuhi prakondisi sustainable economic development (pembangunan ekonomi berkelanjutan); sehingga jelas terlihat mata rantai hubungannya dengan fungsi ekonomi (sebagai Ricardian Rent) dan semakin hilangnya kaitannya dengan fungsi sosial (sebagai Sociological Rent) yang dimiliki tanah; v) Dari segi sosial, kondisi lingkungan 
dan tradisi masyarakat yang relatif sangat variatif dibandingkan dengan kawasan rendah (lowland) mengakibatkan keputusan sosial petaninya sangat berbeda dengan daerah lain; vi) Di tengah kekalutan dunia kehutanan Indonesia saat ini, hutan rakyat masih dapat eksis, karena merupakan salah satu supplier komoditi utama program penghijauan dan rehabilitasi DAS.

Kegagalan memahami dan mengelola hutan justru meminggirkan kearifan lokal dan mengabaikan keberadaan mereka. Pengelolaan dan penguasaan hutan hanya untuk kepentingan modal dan pertumbuhan ekonomi global, dan bukan untuk kepentingan rakyat setempat. Kelalaian akibat keegoisan pemerintah tersebut mengakibatkan terkikisnya pengetahuan lokal (local knowledge) dan kearifan tradisional. Di sisi lain, kegagalan pengelolaan hutan dengan paradigma statebased forest management, tampaknya memenuhi tiga kriteria (Garna; dalam: Elizabeth. 2016), yaitu: 1)proses pembuatan kebijakan publik yang sepihak; 2)partisipasi masyarakat yang kurang dilibatkan keikutsertaannya; akhirnya 3)menimbulkan konflik kepentingan, yaitu antara kepentingan masyarakat dengan kepentingan pemerintah.

Selain itu, perkembangan populasi dan teknologi, kemiskinan dan gaya hidup, pudarnya adat, dan sebagainya juga diprediksi sebagai pemicunya. Masalah pertumbuhan penduduk yang berkembang pesat tentunya berpengaruh pada kegiatan perluasan lahan pertanian dan peternakan untuk mencukupi kebutuhan hidup yang semakin terbatas dan tinggi nilai ekonomisnya (seperti bahan makanan dan perumahan), dan tingkat kehidupan bersosialisasi itu sendiri. Demi menuju pensejahteraan masyarakat melakukan pengeksploitasian sumber daya alam yang ada (hutan, misalnya), sehingga alam disesuaikan agar mampu memenuhi kebutuhan hidup manusia (di-adjustment tanpa henti). Industri HPH yang memperoleh legitimasi dalam kebijakan pemerintah yang berpijak pada pengembangan investasi untuk pembangunan yang besarannya mempengaruhi jumlah sumber energi yang dibutuhkan, sehingga tingginya nilai kontrak mempengaruhi luasnya hutan yang akan digarap. Terjadilah penebangan hutan secara besar-besaran, yang secara sengaja atau kasat mata sepertinya mengenyampingkan kewajiban untuk melasanakan penanaman kembali (reboisasi).

Kenyataan tersebut juga ditemukan pada komunitas sekitar hutan yang memanfaatkan hutan sebagai sumber pemenuh kebutuhan hidupnya. Dalam kondisi kian sulitnya mencari sumber lain untuk kehidupan, maka mereka semakin keras memperlakukan pengusahaan hutan sekitar lingkungan pemukiman mereka. Justru dengan kondisi tersebut, mereka sering dijadikan kambing hitam pihak terkait untuk menutupi kesewenangan tindakan para 


\section{EKSTENSIFIKASI AGRARIA SEKITAR HUTAN, DILEMA KEBUTUHAN LAHAN USAHATANI \\ DAN TERPINGGIRNYA EKSISTENSI MASYARAKATNYA \\ Roosganda Elizabeth}

pengusaha HPH. Oknum inilah diprediksi sebagai promotor yang memprakarsai penduduk agar melakukan penebangan liar dengan iming-iming bayaran (harga) kayu yang tinggi. Menyikapi hal tersebut, berbagai upaya dilakukan para aktivis LSM dan pemerhati lingkungan untuk menemukan pola pengelolaan sumberdaya agraria hutan, yang bertumpu pada komunitas lokal (Sistem Hutan Kerakyatan/SHK) yang memprakarsai pembentukan KpSHK (Konsorsium pendukung SHK). KpSHK melalui para pendukungnya di berupaya secara proaktif memperjuangkan pengakuan dan legitimasi hukum bagi masyarakat lokal sebagai pemilik sah hak pengelolaan sumberdaya hutan secara berkelanjutan dan untuk memperoleh pengakuan terhadap hak adatnya.

\section{Partisipatif dan Penciptaan Kebijakan Kondusif: Mendukung Pemberdayaan dan Keberadaan, Serta Kearifan Lokal Masyarakat Sekitar Hutan}

Untuk tumbuh-kembangnya kehutanan dan merealisasikan pemenuhan lahan pertanian masyarakat sekitar hutan, dalam pelaksanaannya dibutuhkan dukungan kebijakan yang kondusif dan meminimumkan hal-hal yang bersifat distortif, yang mampu mengakomodasikan berbagai aspirasi yang berkembang dalam masyarakat. Penciptaan kebijakan kondusif meliputi: i) perbaikan sistem dan mekanisme pemasaran khususnya peningkatan harga jual di tingkat petani; ii) perubahan persepsi sosial terhadap nilai kerja pertanian agar tidak lagi sebagai alternatif terakhir karena kurang terhormat dan tidak mampu mengangkat status kehidupan masyarakat; iii) selektifitas adopsi paket teknologi agar tidak memudarkan peran petani dan menghilangkan pengetahuan lokal (indigenous knowledge). Partisipatif masyarakat dan penduduk sekitar hutan, serta penciptaan kebijakan kondusif ditenggarai dan pekat mengindikasikan sebagai pendukung pemberdayaan dan keberadaan, serta kearifan lokal masyarakat sekitar hutan. Beberapa kriteria pembangunan yang dapat menggerakkan partisipasi masyarakat adalah: 1) peran masyarakat; 2) tranparansi atau keterbukaan; 3) pemahaman ; dan 4) manfaat sebagai insentif.

Partisipasi (peran serta) masyarakat sangat menentukan keberhasilan atau kegagalan suatu kebijakan publik dalam program pembangunan (UU No. 41/1999, tentang Kehutanan, yaitu: pada pasal (2): Penyelenggaraan Kehutanan berazaskan manfaat dan lestari, kerakyatan, keadilan, kebersamaan, keterbukaan dan keterpaduan; pada pasal (3), huruf (d): Penyelenggaraan kehutanan bertujuan untuk sebesar-besar kemakmuran rakyat yang berkeadilan dan berkelanjutan dengan: meningkatkan kemampuan untuk mengembangkan kapasitas dan keberdayaan masyarakat secara partisipatif, berkeadilan dan berwawasan lingkungan sehingga mampu menciptakan kebersamaan sosial ekonomi serta ketahanan terhadap akibat perubahan eksternal. Partisipatif dimaksudkan agar dapat 
menjembatani antara aspirasi dan kebutuhan masyarakat petani di sekitar hutan, sebagai pelaku utama/subyek pembangunan: i) tranparansi/keterbukaan, dengan mengingat bahwa keterbukaan dapat menimbulkan partisipasi masyarakat dalam program pembangunan; ii) pemahaman yang sama atas program pembangunan, yang dapat menimbulkan antusianisme masyarakat untuk berpartisipasi dalam program pembangunan; iii) manfaat atau insentif yang akan mereka peroleh, akan menimbulkan partisipasinya terhadap program pembangunan tersebut. Selain itu, makna partisipatif juga diharapkan dapat menggugah kesadaran publik bahwa terjadinya keberhasilan maupun kegagalan proses pembangunan pertanian dan kehutanan di sekitar hutan bukan tanggung jawab pemerintah semata, melainkan sangat bergantung pada keberhasilan keterlibatan masyarakat petani sekitar hutan dalam penyelenggaraan pembangunan tersebut, dari awal hingga akhir, yang bertujuan untuk meningkatkan kesejahteraan mereka.

Pemberdayaan pada dasarnya merupakan upaya menumbuhkan partisipasi berbagai pihak terkait, terutama pihak yang hendak diberdayakan, yang memungkinkan suatu potensi dapat berkembang dengan cara mendorong, memotivasi dan membangkitkan kesadaran (arousal) akan potensi yang dimiliki (Elizabeth, 2017). Partisipasi dapat dimulai dari perencanaan, pelaksanaan, hingga monitoring dan evaluasi mencerminkan upaya mewujudkan kemandirian yang transparan dan akuntukabel antara komponen pemerintah, masyarakat, dan swasta, yang dilandasi aturan kebijakan untuk berpartisipasi sesuai proporsi dan kompetensi yang dimiliki secara terukur dan berkelanjutan. Kondisi ini dapat berlangsung dengan mengedepankan prinsipprinsip dasar pemerintahan yang baik (good governance), yaitu: 1) partisipatif; 2) tranparansi; 3) akuntabilitas. Faktor pendukung pemberdayaan petani sekitar hutan meliputi: 1) kekuatan solidaritas petani sebagai konsekuensi lahir dan terbentuk dari masyarakat di sekitar hutan tersebut; 2) struktur dan aturan main merupakan produk konstruksi petani itu sendiri sehingga ditaati, dihargai, dan dijunjung tinggi oleh semua anggota masyarakat petani maupun komunitasnya; 3) bersifat informal dengan struktur sederhana dan arah yang adil dan bukan persaingan; 4) persepsi yang baik dari petani maupun buruh tani terhadap kedudukan dan peran usahatani; 5) partisipasi para petani yang tinggi; dan 6)memiliki kemampuan beradaptasi terhadap: agroekosistem setempat, mekanisme pembangunan yang diterapkan, maupun dinamikanya dalam mensiasati kemungkinan eksploitasi oleh petani lapisan atas.

Pemberdayaan petani sekitar hutan merupakan proses yang menghasilkan keberdayaan mereka. Keberdayaan bukan hanya memperoleh manfaat sebesarbesarnya, namun juga keberdayaan dalam memegang amanat dan tanggungjawab 


\section{EKSTENSIFIKASI AGRARIA SEKITAR HUTAN, DILEMA KEBUTUHAN LAHAN USAHATANI \\ DAN TERPINGGIRNYA EKSISTENSI MASYARAKATNYA \\ Roosganda Elizabeth}

menjaga dan mengembangkan fungsi lahan sekitar hutan yang berkelanjutan. Tujuannya sebagai sumberdaya lahan pertanian untuk memenuhi kebutuhan pangan dan kehidupan komunitas sekitar hutan. Bila sumber penghidupan dan ekonomi secara subsisten telah tercukupi, diharapkan mereka tidak terintimudasi dan tergoda iming-iming ekonomi dari pembalakan hutan, karena pada prinsipnya merka sangan menghargai dan menghormati hutan turun temurun. Bukti nyata keberhasilan pengelolaan agraria hutan dan sekitarnya yang adaptif dan inovatif sebagai lahan pertanian diantaranya adalah succes story dari daerah pertanian di puncak Dieng, di Malang, puncak Bogor (Jawa), Berastagi (Medan, Su-Mut), KASS dan Kawasan Agropolitan di Kerinci dan Curup, Bengkulu (Sumatera), Malino, Sinjai, Luwu, dan Tomohon (Sulawesi), Bedugul (Bali) dan berbagai wilayah hutan dan pegunungan lainnya di Indonesia. Dalam hal ini wilayah tersebut umumnya berhasil diusahakan sebagai areal pertanaman berbagai komoditas hortikultura karena sesuai dengan kondisi iklim, ekosistem dan topografi lahan, dimana wilayah sekitar areal pertanian tersebut masih lestari sebagai hutan. Meski demikian, keberhasilan tersebut juga tidak terlepas dari berbagai dampak yang mengakibatkan terjadinya erosi, tanah longsor dan bencana alam lainnya. Namun hal ini lebih diakibatkan human error, dimana beberapa pihak mengenyampingkan bahkan mengabaikan berbagai ketentuan dan persyaratan yang sangat causal, penting dan krusial dalam strategi pengelolaan agraria hutan dan sekitarnya.

Dalam penciptaan kebijakan kondusif yang menunjang pemberdayaan petani dan komunitas sekitar hutan terkait dengan sumber pendapatan, diperlukan beberapa upaya konkrit seperti; 1) melibatkan kembali peran tokoh informal dalam kegiatan penggalangan sosial ekonomi SDM petani; 2) melibatkan tokoh agama dalam membangun etos kerja dan strategi hidup produktif dan hemat; 3) pemberian pelatihan/peningkatan kemampuan SDM petani agar mengarah pada unit ekonomi produktif; dan 4) melakukan pengkaderan generasi muda pertanian di perdesaan. Secara evolutif, pengeluaran rumahtangga petani diefisienkan dan diarahkan ke aktivitas yang hemat waktu dan biaya. Sifat kedinamisan pemberdayaan sebagai faktor utama penyesuaian langkah keseimbangan pada segala perubahan yang terjadi. Dengan bentuk kebijakan kondusif tersebut, diharapkan dapat mengidentifikasikan pihak-pihak pelaku yang terlibat, hubungan antar pelaku, hubungan antar pelaku dengan kondisi sumberdaya hutan, serta perilaku sebagai perwujudan terjadinya proses belajar, sehingga kapabilitas dan adaptabilitas semua pelaku secara bertahap dapat ditingkatkan. Target pemberantasan penjarahan hutan bisa lebih maksimal hasilnya bila terjadi interaksi positip untuk meningkatkan kohesitas hubungan dan tanggungjawab kerja antar 
instansi yang berwenang dan terkait. Perlunya upaya memperkuat potensi atau daya yang dimiliki dengan membuka atau menciptakan aksesbilitas terhadap berbagai peluang yang menjadikannya semakin berdaya (Elizabeth, 2015). Hal tersebut ditempuh dengan melakukan peningkatan kualitas dan kuantitas (good governance) dalam konsolidasi dan koordinasi di antara mereka, serta pemahaman mendalam terhadap aspek dan kriteria pembangunan kehutanan masyarakat.

Beberapa aspek dan kriteria sebagai Prasyarat Pembangunan Kehutanan Masyarakat di Indonesia (Suhardjito; dalam: Elizabeth. 2020), yaitu:

I. Aspek Pertama adalah Substansi, dengan beberapa Kriteria sebagai prasyarat, seperti:

1) mampu mengakomodasikan semaksimal mungkin berbagai aspirasi yang tumbuh dari bawah.

2) memperjelas status pelaku dan objek lain yang diatur, hubungan antar pelaku dan hubungan pelaku dengan sumberdaya hutan atau objek lainnya yang diatur.

3) dapat memberikan bentuk-bentuk insentif ekonomi, sehingga tercipta self interest, untuk berlangsungnya suatu proses pembelajaran, terutama dalam peningkatan, kapasitas, kapabilitas dan adaptability.

4) mampu mengurangi atau bahkan menghilangkan unsur-unsur ketidak pastian.
5) tidak diskriminatif.

6) tidak multi-interpretatif.

7) tidak mengandung unsur single perception yang sempit.

II. Aspek Kedua adalah Proses Penyusunan, dengan beberapa Kriteria sebagai prasyarat, seperti:

1) menggunakan pendekatan bottom-up process.

2) memperhatikan perbedaan dan keragaman kondisi lapangan yang ada.

3) menerapkan asas demokrasi.

4) menerapkan asas transparansi dan partisipatif.

Pemahaman tersebut juga disertai penerapan peraturan (perundang-undangan) sebagai alat ancaman hukuman yang serius dan bukan hanya sebagai gertakan semata, dan yang paling penting adalah menjaga kekonsisten-an pelaksanaan peraturan tersebut. Proses penyusunannya harus transparan dan partisipatif dengan berjalannya asas demokrasi serta melalui mekanisme yang bottom-up (dimulai dari bawah). Pembahasan dan deskripsi tersebut hendaknya mernjadi latar belakang para policy maker dalam menyusun dan membuat serta pengambil suatu kebijakan pemerintah dengan selalu mengantisipasi dampak yang bisa saja timbul di kemudian hari. Penyempurnaan cara atau pola pikir bukan untuk tujuan segolongan/sepihak belaka, melainkan untuk tujuan kebersamaan/semua golongan dan bisa terjaga kelestarian lingkungan keberadaannya. 


\section{EKSTENSIFIKASI AGRARIA SEKITAR HUTAN, DILEMA KEBUTUHAN LAHAN USAHATANI \\ DAN TERPINGGIRNYA EKSISTENSI MASYARAKATNYA \\ Roosganda Elizabeth}

\section{Kesimpulan dan Implikasi Kebijakan}

- Perlu penerapan peraturan (perundangundangan) sebagai alat ancaman hukuman yang serius dan konsisten bukan hanya sebagai gertakan semata. Proses penyusunannya harus transparan dan partisipatif dengan berjalannya asas demokrasi serta melalui mekanisme yang bottom-up.

- Perlu memandang hutan rakyat secara holistik dan mempertimbangkan pengetahuan dan kearifan lokal, serta merestrukturisasi paradigma state-based forest management dengan paradigma community-based forest management, untuk mencapai pembangunan pertanian sekitar hutan yang berkualitas dan tetap memiliki keberlanjutan fungsi hutan serta manfaat selama-lamanya demi terwujudnya kesejahteraan masyarakat sekitar hutan.

- Pengelolaan hutan oleh negara dan swasta (HPH) di Indonesia, berada pada situasi yang sangat memprihatinkan, karena kebablasan dan kesewenangannya memporak porandakan hutan.

- Pemaksaan hak penguasaan sumberdaya hutan sebagai dikuasai oleh negara, menjadikan sumberdaya agraria hutan telah terampas dari fungsinya sebagai pemenuhan kebutuhan hidup masyarakat lokal dan lahan usaha bagi pertanian tradisional.

- Deforestasi dan degradasi hutan umumnya dipicu oleh tindakan egoistis dan kesewenangan suatu pihak yang hanya memikirkan keuntungan pribadi dan sesaat.

- Partisipasi masyarakat sekitar hutan turut menentukan berhasil tidaknya program pembangunan pertanian sekitar hutan, dan merupakan alat mencapai pemberdayaan. Pemberdayaan merupakan target yang dapat terwujud dengan partisipasi masyarakat sekitar hutan.

- Partisipasi (peran serta) masyarakat sekitar hutan sangat menentukan keberhasilan atau kegagalan suatu kebijakan publik dalam program pembangunan, dan merupakan alat/bentuk untuk mencapai pemberdayaan.

- Pemberdayaan merupakan target yang hendak dicapai, yang dapat terwujud dengan adanya partisipasi dari masyarakat sekitar hutan itu sendiri.

- Perlunya mempertahankan dan menjaga hutan rakyat yang sudah ada dan memandang hutan rakyat secara holistik agar tujuan program pembangunan lebih dimungkinkan, sehingga dapat dipakai sebagai landasan untuk membangun kembali dunia kehutanan yang telah porak poranda, serta agar tetap memiliki keberlanjutan fungsi dan manfaat selamalamanya.

\section{DAFTAR PUSTAKA}

Elizabeth. R. 2020. Akselerasi Inovasi Teknologi Spesifik Lokasi Strategi Peningkatan Produksi Di Masa Pandemi Covid-19. Mimbar 
Agribisnis: Jurnal Pemikiran Masyarakat Ilmiah Berwawasan Agribisnis. Vol 1, No 2 (2020): Jan. 2020. Akreditasi Nomor 34/E/KPT/2018 at SINTA 4 (S4) rank. Accreditation is valid from December 10, 2018 to December 10, 2023. DOI: http://dx.doi.org/10.25157/ma.v5i2.24 11

Elizabeth. R. 2019. Peningkatan Dayasaing Tanaman Pangan Melalui Akselerasi Agroindustri Dan Pemberdayaan Kelembagaan Pertanian. Mimbar Agribisnis: Jurnal Pemikiran Masyarakat Ilmiah Berwawasan Agribisnis. Vol 5, No 2 (2019): Juli 2019. Akreditasi Nomor 34/E/KPT/2018 at SINTA 4 (S4) rank. Accreditation is valid from December 10, 2018 to December 10, 2023. DOI: http://dx.doi.org/10.25157/ma.v5i2.24 11

Elizabeth. R. 2017a. Akselerasi Pemberdayaan Dan Peningkatan Kompetensi Dalam Sistem Produksi Untuk Mengatasi Permasalahan Ekonomi Di Indonesia. Volume 2. Issue 1. June 2017. ISSN Cetak: 25285556. ISSN Online: 2528-6226.

Elizabeth. R. 2017. Revitalisasi Industri Produk Olahan Dan Pemberdayaan Lembaga Kemitraan Mendukung Peningkatan Pemasaran, Daya Saing Dan Pensejahteraan Petani Pisang. Journal of Agricultural Scienties. UNES. (Universitas Ekasakti). Padang Sumatera Barat. Volume 2. Issue 1. June 2017. ISSN Cetak: 2528-5556. ISSN Online: 2528-6226.

Elizabeth, R. 2016. Pemberdayaan Petani Dalam Pengelolaan Tanaman Dan Ternak Guna Meningkatkan Kesejahteraan Petani. Prosiding Seminar Nasional Agustus 2016. BPTP Sulawesi Utara. Manado. Badan Litbang Pertanian. Sekretaris Jenderal Pertanian. Kementerian Pertanian.

Elizabeth. R. 2015. Pencapaian Daya Saing Melalui Peningkatan Teknologi Pengolahan, Peningkatan Kelembagaan Dan Pemasaran Produk Pangan Olahan. PERHEPI. Tema: Indonesia Menuju Swasembada
Pangan Dalam Tiga Tahun Kedepan: "Tinjauan Konseptual, Teoritis dan Empiris". Kendari, 9 Maret, 2015.

Elizabeth. R. 2014. Mewujudkan Kemandirian Dan Ketahanan Pangan Melalui Revitalisasi Dan Pengembangan Infrastruktur Pertanian. Konferensi Nasional XVII dan Kongres XVI PERHEPI. IPB International Convention Center (IICC). Bogor.

Elizabeth, R. 2015. Potret Dialektika Persoalan Tenurial Kekayaan Agraria Hutan di Indonesia. Kumpulan Tulisan Program SPD 2010-2020. Institut Pertanian Bogor. Bogor.

Elizabeth, R. 2017. Fenomena Sosiologis Metamorphosis Petani: ke Arah Keberpihakan Masyarakat Petani di Pedesaan yang Terpinggirkan terkait Konsep Ekonomi Kerakyatan. Forum Agro-Ekonomi (FAE) Vol. 26. Juli. 2007. PSE-KP. Bogor.

Kementerian Lingkungan Hidup dan Kehutanan (KemenLHK). 2020. Laporan Tahunan.

KLHK. 2018. Status Hutan dan Kehutanan Indonesia.

Menteri Lingkungan Hidup dan Kehutanan. 2021. Peraturan Menteri Lingkungan Hidup Dan Kehutanan Republik Indonesia Nomor 8 Tahun 2021Tentang Tata Hutan Dan Penyusunan Rencana Pengelolaan Hutan, Serta Pemanfaatan Hutan Di Hutan Lindung Dan Hutan Produksi.

Suhardjito. D. 2010. Kehutanan Masyarakat, Beragam Pola Partisipasi Masyarakat dalam Pengelolaan Hutan. IPB. Bogor

Undang Undang Dasar 1945 pasal 33, ayat (2) tentang penguasaan dan pemanfaatan sebesar-besarnya oleh negara atas seluruh sumberdaya alam Indonesia

Undang Undang No. 41/1999, tentang Kehutanan.

Beberapa statement yang memprakarsai pembentukan KpSHK (Konsorsium pendukung SHK) (Sistem Hutan Kerakyatan/SHK) 